\title{
"Deer" as the Basic Concept of the Enets Language
}

\author{
Ksenia V. Reznikova* \\ Siberian Federal University \\ 79 Svobodny, Krasnoyarsk, 660041, Russia
}

Received 06.03.2018, received in revised form 06.04.2018, accepted 10.04.2018

\begin{abstract}
The article analyses the actual state of the Enets language that most likely risks to extinct in the context of globalization. The situation with the Enets language is one of the most disturbing not only because there are a little more than two hundred representatives of this ethnos left, where less than fifty people speak the Enets language, but also because the Enets language is a non-written language. This article considers ethno-social processes that are characteristic of Enets, analyses the prevalence of the Enets language provided by different sources in several time samples in the period from 1992 to 2017. The article also determines features of the Enets language and the role of the concept "deer" in the forest dialect of the Enets language; and it draws attention to the rights of the Enets in the language sphere that are guaranteed by the regional legislation. The study is summarized by several conclusions that predict the prompt disappearance of the Enets language and assume that without the restoration of reindeer breeding the revival of the Enets language is practically impossible.
\end{abstract}

Keywords: the Enets, Enets language, non-written languages, deer.

The reported study was funded by Krasnoyarsk Regional Fund of Science according to the research project: "Development of scientific and methodological support for the preservation of a unique cultural heritage for the Ket and Enets ethno-cultural groups of indigenous small peoples of the North, Siberia and the Far East living on the territory of the Krasnoyarsk Territory.

DOI: 10.17516/1997-1370-0253.

Research area: culturology.

Introduction. In today's world it becomes increasingly difficult for individual ethnoses to resist their own dissolution in a large society under the pressure of globalization. Maintenance and development of ethnic (or national) language, in particular, helps to keep ethnos's own culture from homogenization and unification. The indigenous minorities of the North faced a threat of their own disappearance most closely, and the decrease in the number of speakers of traditional native languages (which is not typical of all of the small northern ethnic groups, but of many) in one of the reasons. The situation with the Enets culture and the Enets language is one of the most alarming, not only because there are a little more than 200 representatives of this ethnos, with 3645 people (according to various sources) speaking

(c) Siberian Federal University. All rights reserved

* Corresponding author E-mail address: axu-ta@mail.ru 
the Enets language, but also because the Enets language is a non-written language.

Literature review. Obviously, in the context of globalization, non-literate peoples, who whom it is more difficult to maintain their own identity, fell into the risk zone of extinction. Among the non-literate peoples of Russia, the greatest attention in the domestic academic sphere is paid to the ethnoses of the North Caucasus studied by D.Sh. Ramazanova (Ramazanova, 2015), A.I. Khalidov (Khalidov, 2017), A.I. Temirbolatova (Temirbolatova, 2011), M.Sh. Khalilov (Khalilov, 2013), etc. The studies of foreign authors concern, for example, the nonliterate cultures of the peoples of South Africa (Joubert, 1999) and others.

In the opinion of B.B. Dzhamalova, one of the factors contributing to the preservation of the ethnic identity of non-literate peoples is nationally oriented education with an ethno-cultural content (Dzhamalova, 2014). A.N. Niudiurmagomedov also indicates the need for nationally oriented education in connection with the impossibility of the indigenous peoples, whose languages are nonwritten, to transfer traditions to the youth through the fixation in writing (Niudiurmagomedov, 2014). In the absence of written language, education is proposed to be carried out based on material culture, ethnos traditions, etc.

The description of the Enets culture is also given by A.P. Stateinov (Stateinov, 2008), N.P. Makarov and M.S. Batashev (Makarov, 2007), N.V. Malygina (Malygina, 2014), V.K.O. Bicheool (Bicheool, 2013), Iu.N. Kvashnin (Kvashnin, 2009), V.P. Krivonogov (Krivonogov, 2004; Krivonogov, 2007; Krivonogov, 1998), Iu. Shabaev (Shabaev, 2014), K.A. Degtiarenko (Degtiarenko, 2015), V.I. Kirko (Kirko, 2015). N.P. Koptseva, A.N. Khizhniakova and K.V. Reznikova focus on the Enets folklore (Koptseva, 2017).
Linguistic studies of the Enets language were conducted by such scientists as V.Iu. Gusev (Gusev, 2011), Ia.A. Glikhikh, S.V. Glushkov, A.K. Stoliarova (Glukhikh, 2012), O.V. Khanina and A.B. Shluinskii (Shluinskii, 2017; Khanina, 2012; Khanina, 2015; Khanina, 2016), M.A. Ovsiannikova (Ovsiannikova, 2011).

In addition to the study of the Enets culture and cultures of other non-literate peoples, texts that raise questions of the identity of Siberian territory are important for this work (Kistova, 2016; Dvoretskaia, 2017; Kononova, 2017; Seredkina, 2016). These texts present results of the research on the current state of cultures of individual indigenous peoples of the North of the Krasnoyarsk Territory and adjacent territories Chulyms (Bukova, 2016), Yakuts (Kirko, 2017), Yessey Yakuts (Berezhnova, 2018; Berezhnova, 2016) and analyze the main trends in the development or extinction of the traditions of the indigenous peoples (Koptseva, 2014; Kolesnik, 2014; Libakova, 2015a; Libakova, 2015b; Pimenova, 2016; Sitnikova, 2015a; Sitnikova, 2015b).

The Enets as one of the indigenous small-numbered peoples of the North of the Krasnoyarsk Territory. The Enets live mainly in the territory of the Taimyr Municipal District of the Krasnoyarsk Territory. As a rule, researchers dealing with the issues of the Enets culture argue that there are very few Enets left, that they are on the verge of complete assimilation. For example, it is evidenced by Iu.N. Kvashnin: "We are observing the results of the passive adaptation of the ethnos. The Enets, who for a long time adapted to the changes in the cultural and natural environment, came under the influence of the numerous and more adaptable Nenets ethnos. As a result, the Enets lost many elements of their ethnic culture. In the future, it is possible to predict the complete dissolution of the Enets 
of the tundra group among neighbouring peoples and the formal preservation of the Enets identity among the Enets of the forest group" (Kvashnin, 2010: 98).

In 1989, the census recorded about 100 Enets; the expedition of V.P. Krivonogov 1992 recorded 217 people; the expedition data on the number of the Enets as of 2002 (245 people) differ from the data of the population census of the same year (197 people, excluding those living in Norilsk) (Krivonogov, 2004). The 2010 population census recorded 227 Enets (National composition <..., 2010: 20). Changes in numbers are associated not only with demographic processes, but also with ethnic identification and self-identification - a person can change his ideas about his ethnicity several times in his life, as well as be fixed by external institutions belonging to one or another people.

Being an extremely small people, the Enets are threatened with extinction as an ethnos due to the large number of mixed marriages, according to V.P. Krivonogov, "no other indigenous people of Central Siberia has such a high percentage of mixed marriages"; in 1992, in fact, virtually all $100 \%$ of children were of mixed origin, and with a natural change of generations, miscegenation increases more and more" (Krivonogov, 2004: 363).

The peculiarities of their resettlement also do not contribute to the preservation of the Enets: the representatives of this people compactly live in the "Enets" settlements - Vorontsovo and Potapovo, in 1992, $72.8 \%$ of all the Enets lived there, in $2002-57.9 \%$ (Indigenous minorities $<\ldots>$, 2012: 466). But these indicators should be considered in the interrelationship of the Enets with the representatives of other ethnic groups living in these settlements. So, as of 2002, in Vorontsovo there were 43 Enets, which is only $12.4 \%$ of the population of the settlement; by comparison: in the same year there were 219 Nenets in Vorontsovo, or $63.3 \%$ of the population. In 2002 in the Potapovo settlement there were 99 Enets, or $23.8 \%$ of the population; Russians - 106 people, or $25.5 \%$ of the population (Indigenous minorities $<\ldots>, 2012$ : 464-465). In addition, we should note the multiethnicity of the "Enets" settlements: Nenets, Russians, Dolgans, Ukrainians, Germans, Tatars, Belarusians, Uzbeks, Finns, Chuvashes and other peoples also live in each of them.

\section{Indicators of prevalence of the Enets}

language. The Enets language is referred to the Uralic language family, its Samoyedic branch. The Enets language consists of forest and tundra dialects; "speakers of the forest dialect live mainly in Potapovo settlement and Dudinka city, and speakers of the tundra dialect - in Vorontsovo settlement and the Tukhard tundra" (Shluinskii, 2017: 28).

Surveys conducted by A.B. Shluinskyii recorded no more than 45 speakers of the Enets language "with the competence of different levels aged 45 and older" (Shluinskii, 2017: 28). Data collected during the V.P. Krivonogov's expeditions of about the Enets' proficiency in the native language are listed in Table 1 (Krivonogov, 2004).

V.P. Krivonogov gives relative indicators of proficiency in the Enets language, but the absolute values obtained by correlating the number of the Enets and the relative indicators of language proficiency are more vivid (Table 2).

Therefore, comparing the data of Table 2 and data obtained by A.B. Shluinskii (Shluinskii, 2017) we can find a decrease in the number of speakers of the Enets language almost twofold (from 83 to 45 people) within 15 years (from 2002 to 2017). Here it is worth mentioning the data of the All-Russian Population Census of 2010, according to which 36 Enets, 4 Nenets and 1 Evenk speak the Enets language (National Composition <... , 2010: 2128, 2131). 
Table 1. Degree of proficiency in the Enets language

\begin{tabular}{|l|c|c|}
\hline \multicolumn{1}{|c|}{ Indicator } & Data of 1992, \% & Data of 2002, \% \\
\hline The Enets recognizing the Enets language to be native & 50,3 & 33,9 \\
\hline The Enets fluent in the Enets language & 40,4 & 24,1 \\
\hline
\end{tabular}

Table 2. Degree of proficiency in the Enets language (absolute values)

\begin{tabular}{|l|c|c|}
\hline \multicolumn{1}{|c|}{ Indicator } & Data of 1992, people & Data of 2002, people \\
\hline The Enets recognizing the Enets language to be native & 109 & 83 \\
\hline The Enets fluent in the Enets language & 88 & 59 \\
\hline
\end{tabular}

Table 3. Native language of the Enets in different age groups, 2002, \% (Indigenous minorities <..>, 2012: 468)

\begin{tabular}{|l|c|c|c|c|}
\hline \multirow{2}{*}{ Age } & \multicolumn{4}{|c|}{ Native language } \\
\cline { 2 - 5 } & Enets & Nenets & Russian & Dolgan \\
\hline 70 and older & 100 & - & - & - \\
\hline $60-69$ & 100 & - & - & - \\
\hline $50-59$ & 95 & 15 & 25 & - \\
\hline $40-49$ & 73 & 10.4 & 58.4 & 5.4 \\
\hline $30-39$ & 39 & 11.1 & 80.5 & - \\
\hline $20-29$ & 6.5 & 19.5 & 96.5 & - \\
\hline $10-19$ & 1.7 & 3.5 & 100 & - \\
\hline Under 10 & - & 3.8 & & - \\
\hline
\end{tabular}

Table 4. Degree of proficiency in the Enets language in different age groups, 2002, \% (Indigenous minorities <..>, 2012: 469)

\begin{tabular}{|l|c|c|c|c|c|}
\hline \multirow{2}{*}{ Age } & \multicolumn{5}{|c|}{ Proficiency in the Enets language } \\
\cline { 2 - 6 } & Fluent & $\begin{array}{c}\text { With some } \\
\text { difficulties }\end{array}$ & $\begin{array}{c}\text { With significant } \\
\text { difficulties }\end{array}$ & $\begin{array}{c}\text { Understand, but } \\
\text { cannot speak }\end{array}$ & $\begin{array}{c}\text { Lack of } \\
\text { knowledge }\end{array}$ \\
\hline 70 and older & 66,7 & - & 33,3 & - & - \\
\hline $60-69$ & 75 & 12,5 & - & 12,5 & - \\
\hline $50-59$ & 65 & 5 & 20 & 10 & 4,2 \\
\hline $40-49$ & 58,3 & 6,3 & 18,7 & 12,5 & 25 \\
\hline $30-39$ & 22,2 & 2,8 & 11,1 & 38,9 & 41,3 \\
\hline $20-29$ & 4,3 & 2,2 & 6,5 & 45,7 & 86,2 \\
\hline $10-19$ & - & - & 1,7 & 12,1 & 96,2 \\
\hline Under 10 & - & - & - & 3,8 & 42,9 \\
\hline Total & 24,1 & 2,8 & 9 & 21,2 & - \\
\hline
\end{tabular}


In addition to the general figures on proficiency in the Enets language and on recognition of the Enets to be native, the data on the choice of the native language by the Enets (Table 3) and the degree of proficiency in the Enets (Table 4), depending on age, are of particular interest.

The analysis of the data presented in Table 3 reveals several important things. Firstly, less than half of the Enets under the age of 40 consider the Enets to be their native language. Moreover, in the age groups under 30, the Enets language is recognized to be native by less than $10 \%$ of the ethnic group's representatives. Secondly, everything changes in the group of the age of 40 (it should be recalled once again that we are talking about data of 2002): among the Enets older than 40 years, there are more those who call the Enets language native, not Russian (the ratio varies from 100:0 to 73:25); among the Enets under 40 years the situation is the opposite (ratio from 39:58.4 to 0:100). In 2002, people born in 1962 turned 40. Thirdly, no Enets under 10 consider the Enets language to be their native language, even one of the two native languages $(3.8 \%$ of the Enets under 10 recognize both Russian and Nenets to be their mother tongue). Fourthly, one more turning point can be fixed in the ratio of the Enets and Nenets as the native languages of the Enets: there are more those who consider the Enets language to be native, not Nenets (ratio from 100:0 to 39:11.1); among the Enets under 30 the situation is the opposite (ratio from 6.5:19.5 to $0: 3.8$ ). In 2002, people born in 1972 turned 30.

According to the data from Table 4, as of 2002, no Enets under 20 years old spoke the Enets language fluently or at least with some difficulties; the younger the Enets, the worse their proficiency in the Enets.

The decrease in indicators relating to the fluency of the Enets, as well as the Enets' recognition of it to be the native language, is also connected with the lack of the Enets writing language, "although in recent years some representatives of the Enets intelligentsia have been trying to create it. <..> The Enets themselves think that the idea of creating a writing language and teaching it in schools is highly questionable. The idea was supported by $49.7 \%, 12.2 \%$ doubted, $14.3 \%$ were undecided, $23.8 \%$ did not see it necessary" (Indigenous Minorities <...>, 2012: 472).

Features of the Enets language. As was already noted, the Enets language has no written language. Its sounds can be transcribed using the Cyrillic alphabet extended by three additional characters:

$\eta$ - a back consonant sound close to nasal [n]; $\varepsilon-$ a coarsened mid front vowel close to [e];

" - a guttural stop sound.

Z.N. Bolina's "Enets Picture Dictionary" intended for teaching children of the preschool and primary-school age native language (forest dialect) is a reflection of the most important components of life of this ethnos (Bolina, 2012). Analysing one of the parts of this dictionary, a thematic one, we can draw several conclusions: firstly, deer have the greatest importance for the Enets - in the dictionary there are parts devoted to deer as "Deer Fur Varieties" (11 titles); "The names of deer in harness" (10); "Deer" (22); "Harness" (5). Also, some names, including references to deer, are present in other parts, for example, "Defining a person by occupation" (6 out of 18 names are related to a deer, for example, "tenyda - a drover of a herd of deer" (Bolina: 113), "marituda enchi - a person who travels the tundra in order to search for lost deer” (Bolina, 2012: 114), etc.); “tools for men's work" ("Chezy - maut - a long rope braided from rovduga (deer skin) for deer catching" (Bolina, 2012: 106), etc.). By comparison, the part titled "Wild animals" includes 16 names 
in total, "Domestic animals" - 6; two out of six domestic animals are actually a deer (te) and a deer herding dog (te ponida bunyk).

Secondly, the list of domestic animals (6 names) is inferior in number to the lists of wild animals (16), insects (16), birds (21) and fish (12); consequently, the Enets culture is more dependent on the external environment, the inner one is almost entirely focused on deer. Thirdly, the Enets culture is characterized by a division into masculine and feminine traced in various spheres: clothing, tools for work, varieties of sledges.

The concept of "deer" in the forest dialect of the Enets language. The material for the analysis is the thematic section of the Enets Picture Dictionary (Bolina, 2012). This dictionary is aimed at children of preschool and primary school age; therefore, it contains the most important, basic terms for the language. In the thematic section, words are grouped into semantic blocks, which makes it possible to analyse the representation of the "deer" concept in the Enets language within the individual topics through comparing with the representation of other concepts in them; the groupness of terms actually represents the first stage of the analysis of the concept of "deer" in the Enets language.

The term "deer" is presented in the following sections: menswear ( 2 names out of 15 ); hunting gear (1 out of 24); tools for men's work (1 out of 19); parts of a sledge (2 out of 10); women's clothing (4 out of 14); tools for women's work (2 out of 13); food (4 out of 38); months (3 out of 12); insects (1 out of 16); domestic animals (2 out of 6 ); identification of a person by occupation (6 out of 18). It should be noted that the representation of the term "deer" counted only in those cases when a deer was mentioned. For example, we counted "koba pagi - a parka made of deer fur", but the word "tobak - fur stockings (fur inside)" was not counted, since they could be sewn from both deer fur and fur of other animals, etc.
In the dictionary, there are also parts entirely dedicated to a deer or directly related to it: these are sledges (5 titles); harness (5); names of deer in a harness (10); varieties of deer fur (11); deer (22).

Further, on the basis of definitions of Enets words associated with deer, let us analyse, for which aspects of human life it turns out to be the most important; what are the criteria for the classification of deer.

Reindeer husbandry as the main type of economic activity. In section "Identification of a person by occupation" (18 titles in all), the following areas of employment are found: reindeer husbandry (6), education/training (4), man's craft (3), women's craft (2), work in a chum (1).

Reindeer husbandry is graduated by types of employment quite finely: "te ponida - reindeer breeder"; "tenyda - a driver of a herd of deer"; "ezzuda - a person who drives a deer harness"; "marituda enchi - a person who travels the tundra in search for lost deer"; "teadaguza - a shepherd who feeds deer in the daytime"; "bezaa shepherd who guards deer at night".

Types of domestic deer are finely graded as well. The basis of their classification is the following:

- sex (castrated bullate, buck, doe, springer, non-pregnant heifer, young doe, one-year-old doe, two-year-old doe, two-year-old buck);

- age (new-born deer, calf, young doe, one-year-old doe, two-year-old doe, two-year-old buck);

- reproductive characteristics (castrated bullate, springer, non-pregnant heifer);

- a degree of domestication (unhandled deer, docile deer, tamed to eat from hands, wild, domestic, trained to walk in harness);

- a colour of fur that, on the one hand, makes it easier to identify deer in a herd, and on the other hand, it is valued differently in the production of clothing, footwear and household items (with silvery, red, motley, white fur). 
Deer as a means of transportation. Deer differ depending on the place in a harness (leading, next to the leading one, middle, end deer, next to the end deer); in terms of the number of deer there are verbs that denote riding on a harness (harness of two, three, four, five, six deer); male employment is often associated with riding a harness (a person riding a reindeer harness, a man who travels the tundra in search for lost deer, etc.), etc.

Deer as a material source-fur and leather. Men's and women's winter shoes are sewed from deer skin; summer shoes are made of rovduga; a female park - of fur; ropes are made of rovduga; skins are also used in string of sledges. Deer's fur and skin are very valuable. The importance of deer as a material source is emphasized by a wide range of names of types of fur, depending on the following factors:

- age of deer (new-born, monthly calf, autumn calf);

- time of the year when a deer is harvested (August fur, winter, autumn, summer fur);

- part of a deer's body, from which the fur is extracted (neb, legs, whole carcass, feet).

Moreover, different types of fur specify the inventory used in the women's craft: for dressing fur, for finishing deer skin, for making rovduga.

Deer as food. For the Enets, deer meat, fat and milk consumed in different types are in high demand: raw, dried, boiled, stewed.

Deer as a basis for understanding the annual cycle: the Enets associate the names of three months with a deer: "nezy diri - May ("the calf month")"; "kora diri - October ("the month of a domestic male deer")"; "kezar kora deri - November (the month of a wild male deer)". The names of another three months in the Enets language are associated with animals: April is the month of an eagle (arrival of eagles), July is the month of a mosquito (the greatest activity of mosquitoes), August is the month of geese (hunting season); the names of four months are associated with natural phenomena: February - the cold month, June - the month of water, September - the month without leaves, December - the month of great darkness; two months - with seasonal works: January - the month of an ax handle, March - the month of long trips. In fact, the names of four months can be considered associated with a deer, since long migrations (March) are carried out on deer.

Deer as the basis of interconnection of the animal world. Among all dogs ("bunyk") in the Enets language there are those associated with a deer - deer-legged ("te ponida bunyk"); among the gadflies ("piliu") - their larvae under the skin of a deer ("shui").

Having discovered such a significant and fundamental role of the "deer" concept for the Enets language, we should turn to data concerning the current state of reindeer breeding. Thus, in 2002, only $16.4 \%$ of male Enets were engaged in reindeer husbandry, $36.6 \%$ of men named reindeer husbandry to be their first work (Indigenous Minorities <...>, 2012: 466). Moreover, it is noted that "in recent years nomadic reindeer herding has completely disappeared on the right bank, in Potapovo and Vorontsovo, and has been preserved only among Tukhard's Enets dissolving among the predominant Nenets." (Indigenous Minorities <...>, 2012: 468).

\section{Legislation in the sphere of indigenous} languages of the Krasnoyarsk Territory. The Law of the Krasnoyarsk Territory dated November 5, 2015 No. 9-3816 "On the native (national) languages of indigenous small-numbered peoples living in the territory of the Krasnoyarsk Territory", among other things, recognizes the native languages of small-numbered peoples (including the Enets - Article 1.1) to be "the most important element of the ethnic culture of smallnumbered peoples" (Article 1.1). According to the 
Law No. 9-3816, in places of traditional residence of the indigenous small-numbered people and the traditional economy, their native language can be used along with the state language in official spheres of communication (Article 2.2); it can be distributed through the media (Article 7.1); the names of geographical objects, indexes, inscriptions (Article 8) can be made in the native languages.

A particular interest is raised by Art. 9 "The right to choose the language of education and training", paragraph 1 of which reads: "Persons belonging to small-numbered peoples have the right to receive pre-school, primary general and basic general education in their native language, as well as the right to learn their native language within opportunities provided by the education system in accordance with the procedure established by the legislation on education". With respect to the Enets language, this means that the Enets have the right to receive school education in the Enets language, but they cannot use it because of the lack of the possibility of teaching in this language in the education system: "There is no teaching of the language in schools, but so far it happens on a voluntary basis and without much success" (Indigenous minorities <...>, 2012: 472).

\section{Conclusion}

Several conclusions can summarize the article:

There is a decrease in the number of the Enets due to natural demographic processes (mortality), miscegenation and changes in ethnic identity. There are no really "Enets" settlements: in the polyethnic settlements of Vorontsovo and Potapovo that are considered as such, the share of the Enets does not exceed $24 \%$ of the population. It is important to note that in the settlement of Vorontsovo the Nenets are the dominant ethnic group (more than $60 \%$ ), in the Potapovo settlement the largest ethnic group (by the number of people) is Russians (more than $25 \%$ ).
There is a decrease in the number of speakers in the Enets language, according to the data published in 2017, there were no more than 50 Enets (belonging exclusively to the age group over 45) who spoke the Enets language to varying degrees. According to the data of 2002, less than half of the Enets under the age of 40 (born in 1962 and later) considered the Enets to be their native language; Russian was the most common language among this age group. According to the data of 2002, among the Enets under 30 (born in 1972 and later), there are more people who call the Nenets language native, not the Enets language. Extinction of the Enets language is associated with the lack of a written language, although the Enets themselves are ambivalent about the idea of its creation.

Familiarization with the thematic section of the dictionary of the Enets language (forest dialect) made it possible to find out the focus of the Enets culture on the domestic reindeer, as well as the importance of the division into masculine and feminine in it (it concerns clothing, sledges, activities, etc.).

The study made it possible to discover the fundamental role of the concept of "deer" for the Enets language. Reindeer husbandry is represented in the Enets language as the main type of economic activity, a deer - as a means of transportation, as a source of material (fur and skin), as food, as the basis for understanding the annual cycle, as the basis for the interconnection of the animal world.

In 2002, reindeer herding was occupied only by $16.4 \%$ of the Enets, although $36.6 \%$ of the Enets named it the first work. That is, we can talk about the continuing reduction in the number of people engaged in reindeer herding, which has been preserved only in the Tukhard tundra, where the Enets are dissolved among the Nenets.

Regional legislation grants the right not only to use the Enets (as well as any other indigenous language) in the territories of the original 
residence of the Enets in official spheres of communication, for media broadcasting, etc., but also the right to receive preschool and secondary education in the Enets language. But in practice these rights are not realized.

On the basis of the presented conclusions, firstly, it is possible to predict the prompt disappearance of the Enets language, since the number of the Enets as a whole and the number of the Enets who are fluent in the Enets (they are aging) is sharply reducing, as well as the reduction and aging of the Enets who consider the Enets to be native, and not the Russian or the Nenets languages.

Secondly, we can assume that since the concept of "deer" is fundamental for the Enets language, it is practically impossible to revive the Enets language without the restoration of reindeer breeding. A close relationship between reindeer herding, ethnicity and language can be explained by the preference of the Enets born after 1972 to consider not only of the Russian language to be native, but also the Nenets language (the Nenets, unlike the Enets, continue to preserve reindeer herding).

\section{References}

Berezhnova, M.I., Pimenova, N.N. (2018). Istoriia formirovaniia subetnosa esseiskikh iakutov (na materiale analiza nauchnykh issledovanii i arkhiva Krasnoiarskogo kraevogo kraevedcheskogo muzeia) [History of the formation of the sub-ethnos of the Yessey Yakuts (based on the analysis of scientific research and archives of the Krasnoyarsk Regional Museum)]. In Severnye Arkhivy $i$ Ekspeditsii [Northern Archives and Expeditions], 4, 30-52.

Berezhnova, M., Pimenova, N.N. (2016). Rost sotsial'no-kul'turnogo raznoobraziia kak rezul'tat mezhetnicheskikh kommunikatsii: iakuty s ozera Essei [Growth of socio-cultural diversity as a result of interethnic communication: the Yakuts from Lake Yessey]. In Sotsiodinamika [Sociodynamics], 4, 28-40. DOI: 10.7256/2409-7144.2016.4.18296. Available at: http://e-notabene.ru/pr/article_18296.html

Bicheool V.K.O. (2013). Material'naia kul'tura kochevnikov Taimyra (na primere samodiiskikh narodov) [Material culture of Taimyr nomads (on the example of Samoyed peoples)]. In Vestnik Cheliabinskoi gosudarstvennoi akademii kul'tury i iskusstv [Bulletin of the Chelyabinsk State Academy of Culture and Arts], 1(33), 170-174.

Bolina, Z.N. (2012). Enetskii kartinnyi slovar' [Enets Picture Dictionary]. Dudinka: Taimyrskii Dom narodnogo tvorchestva [The Taimyr House of Folk Art], 120 p.

Bukova, M.I. (2016). Osobennosti etnokul'turnogo samosoznaniia etnicheskoi gruppy chulymtsev, kompaktno prozhivaiushchikh na territorii derevni Pasechnoe Tiukhtetskogo raiona Krasnoiarskogo kraia (Tsentral'naia Sibir') [Peculiarities of the ethnocultural identity of the ethnic group of Chulymians who live compactly in the village of Pasechnoe in the Tiukhtetskii District of the Krasnoyarsk Territory (Central Siberia)]. In Sotsiodinamika [Sociodynamics], 4, 41-51. DOI: 10.7256/2409-7144.2016.4.18414. Available at: http://e-notabene.ru/pr/article_18414.html

Degtiarenko, K.A. (2015). Aktual'noe sostoianie korennykh malochislennykh narodov Severa [Actual status of the indigenous small-numbered peoples of the North]. In Sotsiodinamika [Sociodynamics], 10, 39-57.

Dvoretskaia, A.P. (2017). Razvitie Eniseiskogo Severa v postanovleniiakh Krasnoiarskogo kraevogo komiteta Kommunisticheskoi partii Sovetskogo Soiuza. 1940-1971 gody [Development of the Yenisei North in the resolutions of the Krasnoyarsk Territory Committee of the Communist Party of the Soviet Union. 1940-1971]. In Severnye Arkhivy i Ekspeditsii [Northern Archives and Expeditions], 1, 41-50. 
Dzhamalova, B.B. (2014). Kontseptual'nye osnovy natsional'no orientirovannogo obrazovaniia dlia bespis'mennykh narodov Dagestana [Conceptual foundations of nationally oriented education for the non-literate peoples of Dagestan]. In Vestnik Dagestanskogo nauchnogo tsentra Rossiiskoi akademii obrazovaniia [Bulletin of the Dagestan Scientific Center of the Russian Academy of Education], 3, 30-35.

Glukhiy, Ia.A., Glushkov, S.V., Stoliarova, A.K. (2012). Ob issledovaniiakh v oblasti fonetiki trekh samodiiskikh iazykov (entsev, nganasan, sel'kupov) [On research in the field of phonetics of the three Samoyedic languages (Enets, Nganasan, Selkup)]. In Vestnik TGPU [TSPU Bulletin], 10(125), 70-75.

Gusev, V.Iu. (2011). Ocherki po fonetike ischezaiushchikh samodiiskikh iazykov... (entsy, nganasany, sel'kupy): analiz distributsii i fonemnyi sostav [Essays on the phonetics of endangered Samoyedic languages... (Enets, Nganasans, Selkups): analysis of distribution and phonemic composition]. In Uralo-Altayskie issledovaniia [Ural-Altaic Studies], 1(4), 120-121.

Joubert, A., van Schalkwyk, J.A. (1999). War and Remembrance: The Power of Oral Poetry and the Politics of Hananwa Identity. In Journal of Southern African Studies, 25(1), 29-47.

Khalidov, A.I. (2017). Ecolinguistic Problems of the North Caucasus in the Context of Language Policy. In Journal of Siberian Federal University. Humanities \& Social Sciences, 1(10), 25-39.

Khalilov, M.Sh. (2013). Bezhtintsy i bezhtinskii iazyk [The Bezhts and Bezhta language]. In Rodnoi iazyk: lingvisticheskii zhurnal [Mother language: linguistic journal], 1, 135-145.

Khanina, O.V., Shluinskii, A.B. (2012). Emfaticheskie otritsatel'nye glagoly v enetskom iazyke [Emphatic negative verbs in the Enets language]. In Vestnik TGPU [TSPU Bulletin], 1 (116), 115-121.

Khanina, O.V., Shluinskii, A.B. (2015). Priamoi ob'yekt v enetskom iazyke: ob'ektnoe soglasovanie glagola [Direct object in the Enets language: object matching of the verb]. In Tipologiia morfosintaksicheskikh parametrov [Typology of morphosyntactic parameters], 392-410.

Khanina, O.V., Shluinskii, A.B. (2016). Enetskiy perfekt: diskursivnyye upotrebleniya v evidentsial'no-admirativnogo perfekta [Enetsky perfekt: discursive use in the evidential-admiral perfect]. In Acta Linguistica Petropolitana. Trudy Instituta lingvisticheskikh issledovaniy [Acta Linguistica Petropolitana. Proceedings of the Institute of Linguistic Research], 2(12), 425-474.

Kirko V.I., Kuznetsova Yu.S., Malakhova, Ye.V., Vasil'yev, Ye.A. (2017). Otsenka kachestva zhizni zhiteley rayona Arkticheskoy zony na primere poselka Respubliki Sakha (Yakutiya) [Evaluation of the quality of life of residents of the Arctic zone in the example of the Sakha Republic (Yakutia)]. In Severnyye Arkhivy i Ekspeditsii [Northern Archives and Expeditions], 3, 21-37.

Kirko, V.I. (2015). Postsovetskie praktiki sokhraneniia etnokul'turnoi identichnosti korennykh narodov Severa i Sibiri v Krasnoiarskom krae Rossiiskoi Federatsii [Post-Soviet practices of preserving the ethno-cultural identity of the indigenous peoples of the North and Siberia in the Krasnoyarsk Territory of the Russian Federation]. In Sotsiodinamika [Sociodynamics], 6, 113-133.

Kistova, A.V., Zamaraeva, I.S., Pimenova, N.N., Reznikova, K.V., Koptseva, N.P., \& Seredkina, N.N. (2016). Regional Peculiarities in Modernization Processes within the Territories of Central Siberia. In International Review of Management and Marketing, 6(4). 857-865.

Kolesnik, M.A. (2014). Obzor izucheniia fol'klora korennykh narodov Severa [A review of the study of the folklore of the indigenous peoples of the North]. In Litera, 3, 39-59. DOI: 10.7256/24098698.2014.3.13998. Available at: http://e-notabene.ru/fil/article_13998.html

Kononova, E.S. (2017). Metodicheskie aspekty upravleniia ustoichivym sotsial'noekonomicheskim razvitiem severnykh territorii regiona [Methodological aspects of managing the 
sustainable social and economic development of the northern territories of the region]. In Severnye Arkhivy $i$ Ekspeditsii [Northern Archives and Expeditions], 3, 38-43.

Koptseva, N.P. (2014). K voprosu o gosudarstvennoi politike v oblasti sokhraneniia iazykov korennykh malochislennykh narodov Severa [On the issue of state policy in the field of preservation of indigenous languages of the North]. In Arktika i Sever [Arctic and North], (16). 34-40.

Koptseva, N.P., Khizhniakova, A.N., Reznikova, K.V. (2017). K voprosu o kontseptakh iazykov korennykh narodov Krasnoiarskogo kraia [On the issue of the concepts of the indigenous languages of the Krasnoyarsk Territory]. In Severnyye Arkhivy i Ekspeditsii [Northern Archives and Expeditions], 1, 6-22.

Korennye malochislennye narody Severa i Sibiri v usloviiakh global'nykh transformatsii (na materiale Krasnoiarskogo kraia). CH. 1. Kontseptual'nye i metodologicheskie osnovy issledovaniia. Etnokul'turnaia dinamika korennykh malochislennykh narodov Krasnoiarskogo kraia [Indigenous minorities of the North and Siberia under conditions of global transformations (based on the material of the Krasnoyarsk Territory). Part 1. Conceptual and methodological bases of research. Ethno-cultural dynamics of indigenous smallnumbered peoples of the Krasnoyarsk Territory] (2012). Krasnoyarsk: SFU, 640 p.

Krivonogov, V.P. (1998). Etnicheskie protsessy u malochislennykh narodov Srednei Sibiri [Ethnic processes in the small peoples of Central Siberia]. Krasnoyarsk: KGPU, 320 p.

Krivonogov, V.P. (2004). Entsy v nachale XXI veka [The Enets in the beginning of the 21 ${ }^{\text {st }}$ century], In Etnosy Sibiri. Proshloe. Nastoiashchee. Budushchee. Materialy mezhdunarodnoi nauchnoprakticheskoi konferentsii [Ethnoses of Siberia. The past. The present. The future. Proceedings of the International Scientific and Practical Conference]. Krasnoyarsk, 361-365.

Krivonogov, V.P. (2007). Narody Taimyra v nachale XXI veka [The peoples of Taimyr in the early $21^{\text {st }}$ century]. Krasnoyarsk: KGPU, 418 p.

Kvashnin, Iu.N. (2009). Osobennosti razvitiia etnicheskikh i sotsial'no-ekonomicheskikh protsessov v nizov'iakh Eniseia v XX - nachale XXI vv. [Peculiarities of the development of ethnic and socio-economic processes in the lower reaches of the Yenisei in the $20^{\text {th }}$ - early $21^{\text {st }}$ centuries]. In Vestnik arkheologii, antropologii i etnografii [Bulletin of Archeology, Anthropology and Ethnography], 10, 102-112.

Libakova, N.M. (2015). Formirovanie pozitivnoi etnicheskoi identichnosti indigennykh narodov posredstvom dekorativno-prikladnogo iskusstva (rez'ba po kosti) [Formation of positive ethnic identity of indigenous peoples through arts and crafts (bone carving)]. In Sovremennye problemy nauki i obrazovaniia [Modern problems of science and education], (1-1),1887.

Libakova, N.M. (2015). Upravlenie zdravookhraneniem dlia korennykh narodov Tsentral'noi Sibiri (na materiale analiza Krasnoiarskogo kraia) [Health management for the indigenous peoples of Central Siberia (based on the analysis of the Krasnoyarsk Territory)]. In Trendy i upravlenie [Trends and management], 4, 380-394. DOI: 10.7256/2307-9118.2015.4.16854

Makarov, N.P., Batashev, M.S. (2007). Istoriia i kul'tura narodov Prieniseiskogo kraia [History and culture of the people of the Yenisei region]. Krasnoyarsk: SFU, $246 \mathrm{p}$.

Malygina, N.V. (2014). Taymyr Indigenous People Economy Formation as a Historical Process of Colonization: Feature Ethnographic Story. In In the World of Scientific Discoveries, 9.3(57), 1115-1128.

Natsional'nyi sostav i vladenie iazykami, grazhdanstvo [National composition and language proficiency, citizenship] (2010). In Vserossiiskaia perepis' naseleniia-2010 [All-Russian Population Census-2010]. Available at: http://www.gks.ru/free_doc/new_site/perepis2010/croc/perepis_itogi1612.htm 
Niudiurmagomedov, A.N., Dzhamalova, B.B. (2014). Etnokul'turnoe obrazovanie dlia bespis'mennykh narodov [Ethnocultural education for non-literate peoples]. In Gumanitarnye, sotsial'no-ekonomicheskie $i$ obshchestvennye nauki [Humanitarian, socio-economic and social sciences], 3, 176-179.

Ovsiannikova, M.A. (2011). Topikalizatsiia posessora $\mathrm{v}$ lesnom dialekte enetskogo iazyka [Topicalization of a possessor in the forest dialect of the Enets language]. In Acta Linguistica Petropolitana. In Trudy Instituta lingvisticheskikh issledovanii [Acta Linguistica Petropolitana. Proceedings of the Institute of Linguistic Research], 3(7), 153-159.

Pimenova, N.N. (2016). Mekhanizmy sotsiokul'turnykh izmenenii korennykh malochislennykh narodov Sibiri i Severa: kontseptsiia kul'turnoi travmy P. Shtompki [Mechanisms of sociocultural changes of indigenous small peoples of Siberia and the North: P. Shtomka's concept of cultural trauma]. In Sotsiodinamika [Sociodynamics], 3, 37-45. DOI: 10.7256/2409-7144.2016.3.18210. Available at: http://e-notabene.ru/pr/article_18210.html

Ramazanova, D.Sh. (2015). Iazykovaia politika v Dagestane: istoricheskii aspekt [Language policy in Dagestan: a historical aspect]. In Teoria i praktika obshchestvennogo razvitiia [Theory and practice of social development], 9,169-174.

Seredkina, N.N. (2016). Teoreticheskaia model' pozitivnoi etnicheskoi identichnosti i mekhanizmy ee formirovaniia [Theoretical model of positive ethnic identity and the mechanisms of its formation]. In Sotsiodinamika [Sociodynamics], 2, 37-46. DOI: 10.7256/2409-7144.2016.2.17690. Available at: http://e-notabene.ru/pr/article_17690.html

Shabaev, Iu.P. (2014). Entsy [The Enets]. In Ural'skaia iazykovaia sem'ia: narody, regiony i strany [Uralic language family: peoples, regions and countries], 649-651.

Shluinskii, A.B. (2017). Vidovaia sistema enetskogo iazyka na fone russkoi: k tipologii slovoklassifitsiruiushchego vida [Species system of the Enets language against the background of the Russian language: to the typology of the word classifying species]. In Voprosy iazykoznaniia [Questions of Linguistics], 3, 24-52.

Sitnikova, A.A. (2015). Demografiia i migratsiia v poselkakh korennykh malochislennykh narodov Krasnoiarskogo kraia (poselki Pasechnoe, Essei, Surinda, Farkovo, Nosok, Karaul) [Demography and migration in the villages of the indigenous peoples of the Krasnoyarsk Territory (Pasechnoe, Yessey, Surinda, Farkovo, Nosok, Karaul)]. In Sovremennye problemy nauki i obrazovaniia [Modern problems of science and education], (1-1), 1881-1881.

Sitnikova, A.A. (2015). Korennoe obrazovanie: aktual'noe sostoianie i problemy [Native education: current status and problems]. In Pedagogika i prosveshchenie [Pedagogy and education], (3), 300-311.

Stateinov, A.P. (2008). Malochislennye narody Severa [Small-numbered peoples of the North]. Krasnoyarsk: Bukva, 192 p.

Temirbolatova, A.I. (2011). Problemy iazykovoi politiki i iazykovogo stroitel'stva [Problems of language policy and language construction]. Stavropol', $314 \mathrm{p}$.

Zakon Krasnoiarskogo kraia "O rodnykh (natsional'nykh) iazykakh korennykh malochislennykh narodov, prozhivaiushchikh na territorii Krasnoiarskogo kraia” [Law of the Krasnoyarsk Territory "On the native (national) languages of the indigenous small peoples living on the territory of the Krasnoyarsk Territory”] (2015). Available at: http://docs.cntd.ru/document/430668760 


\title{
«Олень» как основополагающий концепт \\ энецкого языка
}

К.В. Резникова

Сибирский федеральный университет Россия, 660041, Красноярск, пр. Свободньй, 79

\begin{abstract}
Настоящчее исследование посвящено анализу актуального состояния энецкого языка как одного из находящихся в группе риска исчезновения в условиях глобализащии. Ситуация с энецким языком является одной из наиболее тревожных не только потому, что представителей данного этноса насчитывается чуть более двухсот, из них владеющих энецүким языком - менее пятидесяти, но такюе и по причине того, что энецкий является бесписьменным языком. В настоящей статье рассматриваются этносоциальные процессы, характерные для энцев; анализируются показатели распространенности энецкого языка, предоставленные разными источниками в нескольких временных срезах в период с 1992 по 2017 г2.; фиксируются особенности энецкого языка; уточняется роль кониепта «олень» в лесном диалекте энецкого языка; обращуается внимание на права энщев в языковой сфере, гарантированные региональным законодательством. Подытоживается проведенное исследование несколькими выводами, на основе которых прогнозируется скорейшее исчезновение энецкого языка и делается предположение о том, что без восстановления оленеводства возрождение энецкого языка практически невозможно.
\end{abstract}

Ключевые слова: энщуы, энецүкий язык, бесписьменные языки, олень.

Исследование выполнено при поддержке Красноярского краевого фонда науки в рамках реализаџии проекта: «Разработка научно-методического обеспечения сохранения уникального культурного наследия для кетской и энецкой этнокультурных групп коренных малочисленных народов Севера, Сибири и Дальнего Востока, проживающих на территории Красноярского края.

Научная специальность: 24.00.00 - культурология. 